\title{
糖尿病ラットにおける気管腺漿液細胞の変化
}

\author{
広島大学医学部耳鼻咽喉科学教室（主任：原田康夫教授） \\ 津 田哲也

\section{CHANGES IN SEROUS ACINAR CELLS OF THE TRACHEAL GLAND IN DIABETIC RATS}

\author{
TETSUYA TSUDA, M.D.
}

Department of Otolaryngology, Hiroshima University School of Medicine, Hiroshima

Histochemical and ultrastructural changes in tracheal glands of rats with artificially induced diabetes were studied. The diabetic condition was induced by streptozotosine.

The tracheal gland is composed of a duct and secretory units, mucus tubules and serous acini in diabetic as well as normal rats. In normal rats, the serous acinar cells contained only neutral polysaccharides. In diabetic rats, on the other hand, the serous acinar cells contained not only neutral but also moderate amounts of what appeared to be sialic acid containing compounds.

On the ultrastructural level, two kinds of serous cells were observed in diabetic rats, one of which contained homogeneous granules while the other containing heterogeneous granules. The ratio between the number of cells containing heterogeneous granules and cells with homogeneous granules increased with the duration of the diabetic condition in the rat.

Changes within the serous cells of diabetic rats might depress tracheal host defense mechanisms and could explain why airway infections are common in patients suffering from diabetes.

Key words : 糖尿病, 気道感染, 感染防御機構, 気管腺腺細胞

A $96-1297-71610$

\section{I . 緒言}

糖尿病の合併症として, 動脈硬化, 易感染性などか゚ あげられるが，呼吸器においても糖尿病は時に重篤な 感染症を引き起こし, 特に糖尿病患者における感染症 では上気道感染症が多いとされている1．気道におい ては病原性異物の進入を防き排除するために，種々の 防御機構が存在し, 粘液線毛クリアランスは呼吸器の クリアランスの主体をなしている．粘液線毛クリアラ ンスは上皮内線毛細胞の線毛運動と粘液層により規定 され，後者は主として粘液下の気管腺よりの分泌物で 形成され，さらにそこからは感染防御物質としてペル オキシダーゼ, IgA 等が合成, 分泌される21.

糖尿病に際し気道感染症を合併しやすい理由の詳細
を明らかにするため，特に粘液線毛クリアランスにか かわる気管腺の変化を，膵 $\beta$ 細胞を選択的に破壊する ストレプトソトトシン投与により人工的に惹起された糖 尿病ラットを用いて組織化学的, 形態学的に観察し, 検討を加えた。

\section{II. 材料书よU゙方法}

楉尿病ラット作製のため $40 匹 04$ 週齢のウイスター 系ラットを購入し，体重 $100 \mathrm{~g}$ あたりストレプトゾト シン $6.5 \mathrm{mg}$ をクエン酸緩衝液 $0.2 \mathrm{ml}$ に溶解し, 尾静 脈より 1 回投与した。投与後 $1 \sim 7$ カ月にてネンブタ ール深麻醉下にて気管上部を摘出し同時に血清中の血 糖值を市販キット(グルコーステストWako, 和光純 
薬）にて測定した。 また，対照群として 4 週秢のウイ スター系ラットに体重 $100 \mathrm{~g}$ あたりクエン酸緩衝液 $0.2 \mathrm{ml}$ のみを尾静脈より投与し, 同時期に気管上部を 摘出した。

光学䫒微鏡観察 :

摘出した試料は直ちに 4 \%パラホルムアルデヒド溶 液にて固定, エタノール脱水, キシレン透徽後, パラ フィン包埋し $3 \mu$ 厚の連続切片を作製した. 切片は脱パ ラフィン後, 一般染色としてへマトキシリン・エオジ ン染色を行った.

糖質の検索のためには，1）糖質の糖鎖の識別には 過ヨウ素酸 Schiff (PAS) 反応，2）糖質の酸度の識別 には, アルシアンブルー $\mathrm{pH} 2.5$ と PASの二重染色 (AB2.5-PAS) および, アルシアンブルー $\mathrm{pH} 1.0$ と

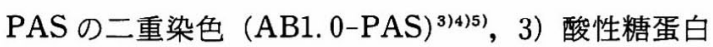
質中のシアル酸の有無についてはメタノールによるメ チル化処理後, AB2.5 染色を行った ${ }^{6)}$.

電子顕微鏡観察 :

一般形態観察のためには $1 / 2$ 強度の Karnovsky ${ }^{7)}$ 液 $(2.5 \%$ グルタールアルデヒド $+2 \%$ パラフォルムア ルデヒド）にて固定した試料をオスミウムにて後固定 し, エタノール脱水, プロピレンオキサイドに置換後, エポン包埋, 超薄切片を作製し酢酸ウランとクエン酸 鉛の二重染色を行った. また糖質の検出のためにはオ スニウムによる後固定を行わずエポン包埋し, 超薄切 片に過ヨウ素酸-チオカルボヒドラジドープロテイン銀 染色 ${ }^{899}$ を行い.いずれも JEM100CXII 透過型電子顕 微鏡で観察した.

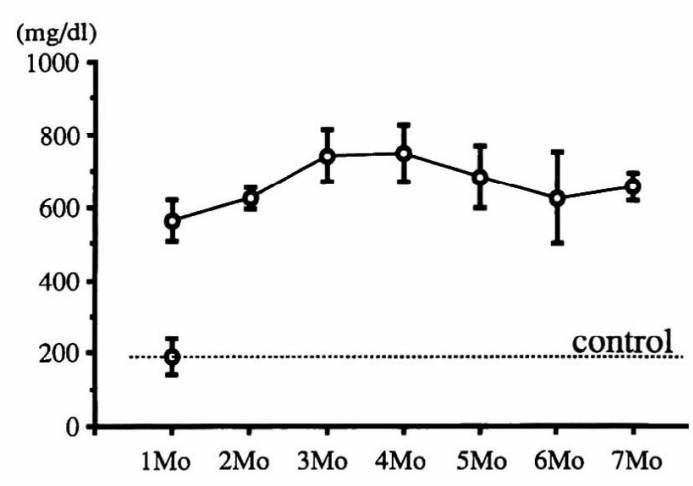

図 1 糖尿病状態の期間による血糖値の変化 血糖はストレプトゾトシン投与後 1 カ月 で，すでに高值を示し， 3 力月まで上昇し たのちほほ同様の值を推移した.

\section{III. 結果}

糖尿病状態の期間による血糖值の変化：

ストレプトゾトシン投与後 1 カ月ではすでに血糖值 は高值を示し， 7 カ月においても高值を維持した。対 照群では加齢による血糖值の変化は認められなかっ た. (図 1).

組織学的および組織化学的所見:

対照群ラットにおいて, 気管腺は粘液細胞からなる 粘液管と漿液細胞からなる漿液腺房により構成されて いた (図 2 )。糖質の検索から, 粘液細胞は $\mathrm{AB}, \mathrm{PAS}$ 両者に陽性であったが，漿液細胞はPAS 反応のみに 陽性で，中性多糖が主体をなしていた（図 3).

糖尿病状態 3 カ月のラットにおいて, 気管腺の分布 状態は対照群のものと著差はなかった(図 4).しかし, AB2. 5 と PAS の二重染色では一部の漿液細胞の分泌 顆粒が青紫色に染色され，中性多糖および酸性多糖の 両者を含んでいた（図 5 ). この酸性多糖は AB1.0で は陰性で,メチル化 AB2.5でも陰性となることから, シアル酸を主体とした弱酸性多糖であった，粘液細胞 については糖尿病による変化はほとんど見られず, 強 酸性多糖を含む細胞がわずかに増加しているのみであ つた.

\section{電子顕微鏡観察 :}

対照群ラットの気管腺粘液細胞は, 電子密度の低い 明るい基質 (halo) と電子密度の高い小さな芯 (core) からなる二相性顆粒を示した（図 6). 漿液細胞では, 核の周囲にはタンパク合成の場である粗面小胞体が層 板状に良く発達しており，また核上部では内部が光電

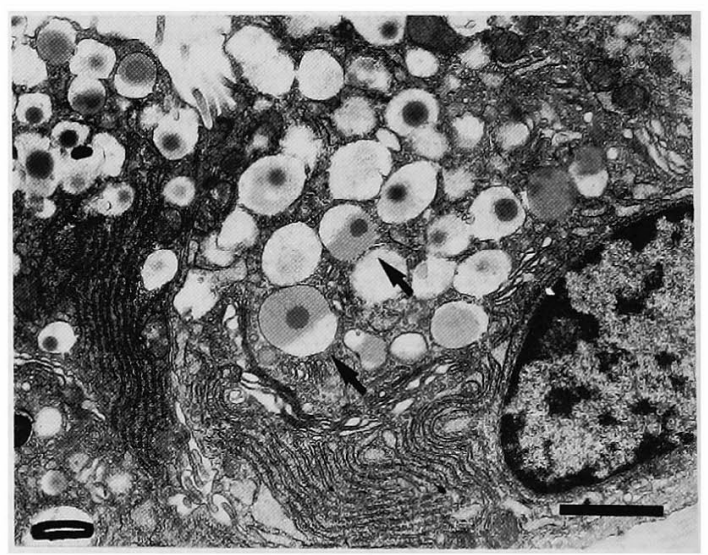

図 6 対照群ラット粘液細胞 $(\mathrm{Bar}=1 \mu \mathrm{m})$ 電子密度の低い明るい基質 (halo) と, 電 子密度の高い芯 (core) からなる二相性顆 粒 (矢印). 


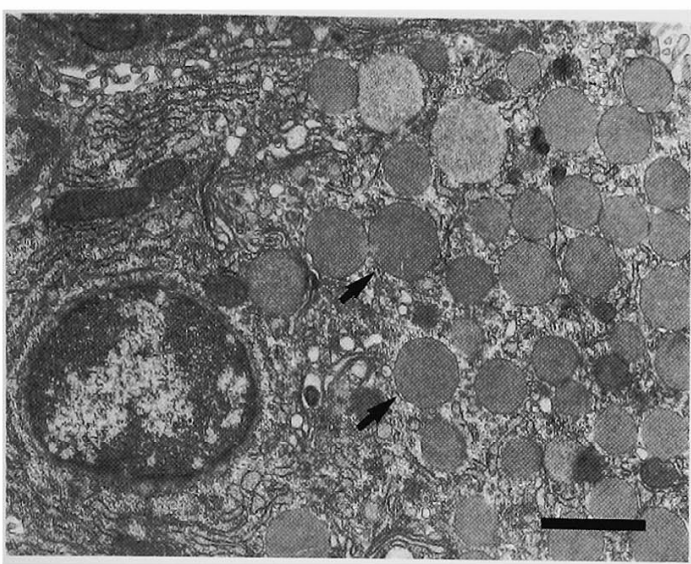

図 7 対照群ラット漿液細胞 $(\mathrm{Bar}=1 \mu \mathrm{m})$

核の周囲にはタンパク合成の場である粗面 小胞体が層板状によく発達しており, 核上 部では内部が高電子密度で均質な形態の夕 ンパクに富む分泌顆粒（矢印）が多く見ら れる。

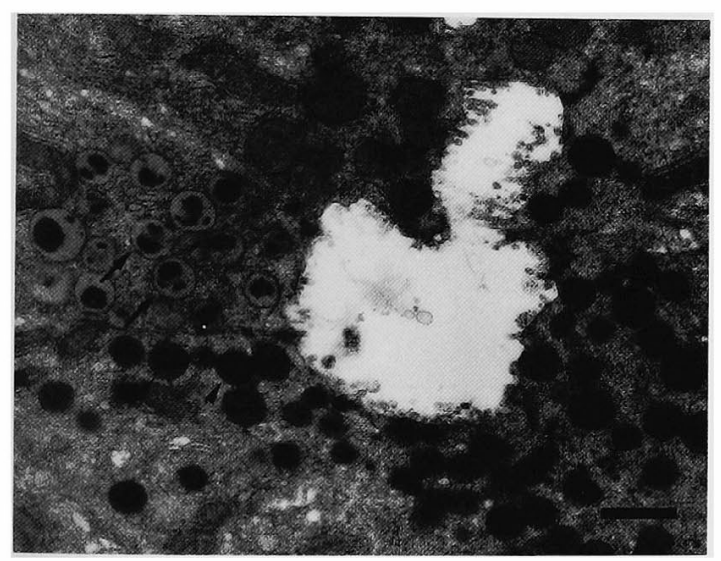

図 8 糖尿病状態 3 力月漿液細胞 $(\mathrm{Bar}=1 \mu \mathrm{m})$ 対照群と同様の内部が高電子密度で均質な 分泌顆粒（矢頭）を含む細胞に加え, 粘液 細胞の分泌顆粒に類似した低電子密度の明 るい基質内に高電子密度の不規則な形状を 示す凝集物をもつ顆粒（矢印）を含む細胞 が混在して認められる.

子密度で均質な形態のタンパクに富む分泌顆粒が多く 見られた（図 7)。糖尿病ラットては，粘液細胞では対 照群と著差は認められなかった。墏液細胞では対照群 と同様の内部が光電子密度で均質の分泌顆粒を含む細 胞に加え, 粘液細胞の分泌顆粒に類似した低電子密度 の明るい基質内に高電子密度の不規則な形状を示す凝 集物をもつ顆粒を含む細胞が混在して認められた（図 $8)$. 糖尿病状態 7 力月になるとほとんどの漿液細胞が

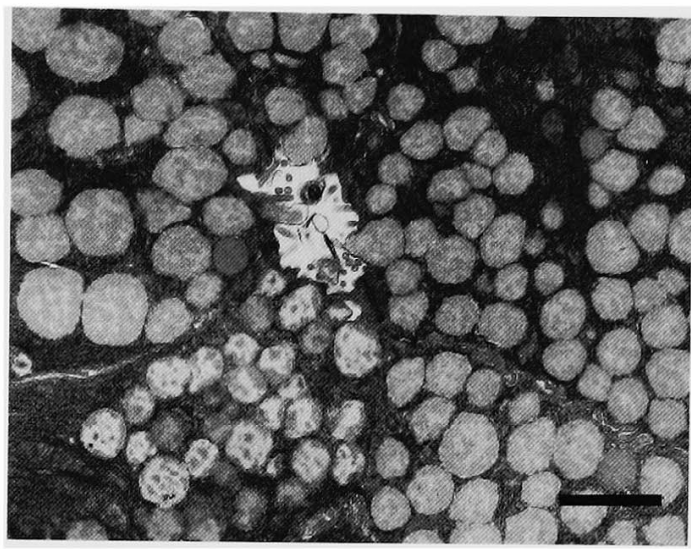

図 9 糖尿病状態 7 力月漿液細胞 $(\mathrm{Bar}=1 \mu \mathrm{m})$ 糖尿病状態 7 カ月になると，ほとんどの漿 液細胞が内部が不均質な分泌顆粒を含む。

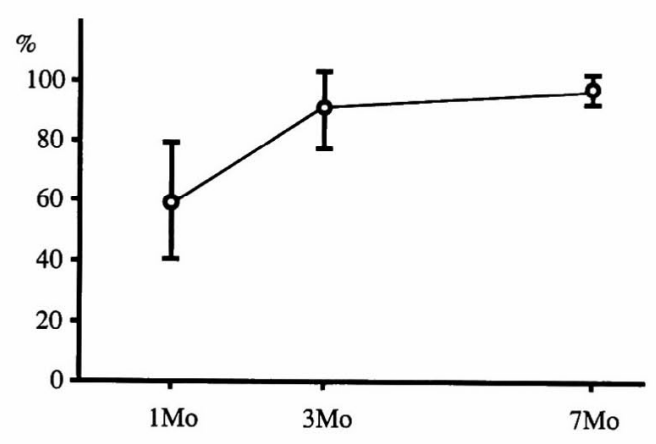

図10 糖尿病状態での䊢液腺房における小葉ごと の粘液化した顆粒の出現率

電子顕微鏡で各個体ごとに，気管上部より 得た切片上に認められた漿液腺房につい て, 粘液様顆粒を有する細胞の比率を算出. 糖尿病状態 1 力月のものと比べ 3 力月, 7 カ月と糖尿病状態が長びくにつれ出現する 割合が増加した。

内部が不均質な分泌顆粒を含んでいた(図 9).ささらに 電子顕微鏡下で, 各個体ごとに気管上部の 3 力所より 得た切片上に認められた漿液腺房について, この粘液 様顆粒を有する細胞の比率を算出した結果, 糖尿病状 態 1 カ月のものでは $59 \pm 19 \% ， 3$ カ月では $91 \pm 12 \%$, 7 カ月では $97 \pm 5 \%$ と糖尿病状態が長引くにつれ出現 する割合が増加した（図10）。

墏液細胞のゴルジ装置の形態は, 対照群ラットでは トランス側の濃縮胞は内部が均質で低電子密度であっ たが，粘液様顆粒を有する糖尿病ラットの漿液細胞て は濃縮胞の内部は電子密度は低いもののすでに不均質 となっていた(図11，12).さらに，ゴルジ装置のトラ 


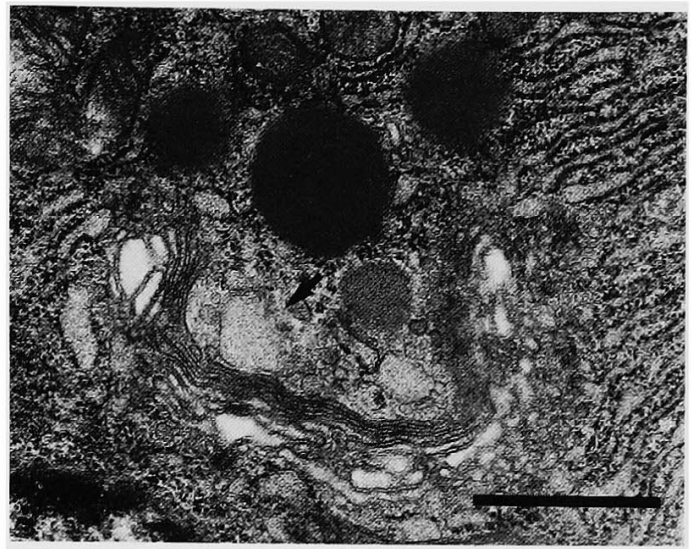

図11対照群ラット漿液細胞ゴルジ装置 $(\mathrm{Bar}=1 \mu \mathrm{m})$

ゴルジ装置のトランス側の濃縮胞（矢印） は内部が低電子密度で均質である.

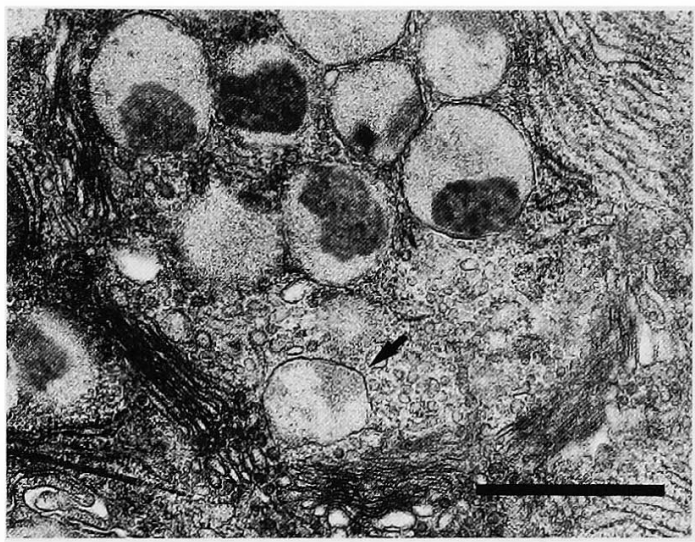

図12糖尿病状態 3 力月漿液細胞ゴルジ装置 $(\mathrm{Bar}=1 \mu \mathrm{m})$

濃縮胞（矢印）の内部は電子密度は低いも ののすでに不均質となっている.ゴルジ装 置のトランス側では, 対照群と比較して多 数の小胞状構造により示されるトランスゴ ルジネットワーク (TGN) の発達が認めら れる。

ンス側では，コントロールと比較して多数の小胞状構 造により示されるトランスゴルジネットワーク (TGN) の発達が認められた（図12).

糖質の検出のための, 過ヨウ素酸-チオカルボヒドラ ジド-プロテイン銀染色では, 糖尿病ラットの漿液細胞 の分泌顆粒において, 醋酸ウランとクエン酸鉛の二重 染色で粘液顆粒に類似した低電子密度の明るい気質が 陽性で, タンパク部分である高電子密度の凝集部分が 陰性であった（図13，14）。

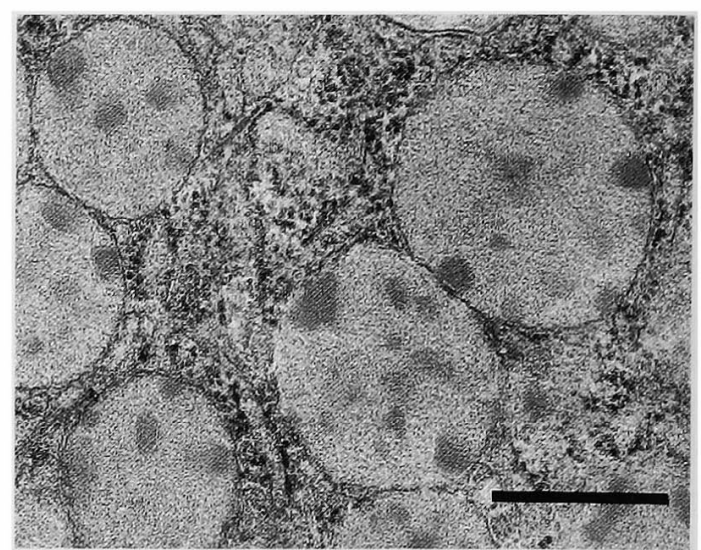

図13糖尿病状態 3 力月漿液細胞分泌顆粒 $(\mathrm{Bar}=0.5 \mu \mathrm{m})$

低電子密度の明るい基質と, 高電子密度の 凝集物をもつ分泌顆粒.酢酸ウランークエン 酸鉛の二重染色.

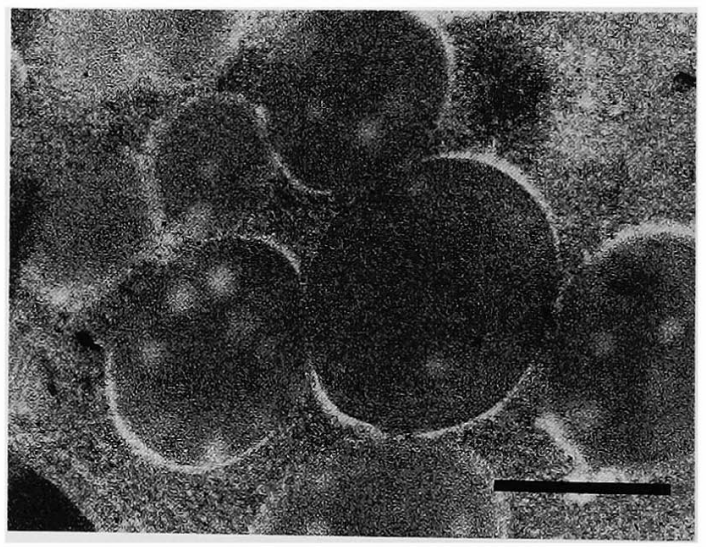

図14糖尿病状態 3 力月漿液細胞分泌顆粒 $(\mathrm{Bar}=0.5 \mu \mathrm{m})$

酢酸ウランとクエン酸鉛の二重染色で粘液 顆粒に類似した低電子密度の明るい基質が 陽性で, タンパク部分である高電子密度の 凝集部分は陰性である。過ヨウ素酸-チオカ ルボヒドラジトープロテイン銀染色.

\section{IV. 考察}

糖尿病患者の併発感染症としては, 上気道, 尿路, 肺炎, 皮層・軟部組織感染症などが上位を占め, その 中で上気道の感染症が最も頻発する ${ }^{11}$. 呼吸器におい ては感染防御機構としての種々のクリアランスや感染 防御物質が存在するが, 糖尿病がそれらにどのような 影響を及ぼすか, ラットの糖尿病モデルの気管粘膜の 気管腺腺細胞に着目し, 組織化学的ならびに形態学的 に検索をした。 
組織化学的な検索では, 粘膜細胞は糖尿病ラットに おいても著明な変化は見られなかったが，漿液細胞で は著しい変化が認められた。すなおち, 対照群では PASのみに陽性で中性多楉のみが含まれるのに対し， 糖疗病ラットでは AB2.5 で漿液腺房の一部の細胞の 分泌顆粒が青紫色に染色され，中性多糖のみならず酸 性多楉も含んでいた。酸性ムコ多糖は, カルボキシル 基 $(-\mathrm{COOH})$ をもつシアル酸ムコ多糖と, 硫酸基 (一 $\left.\mathrm{SO}_{3} \mathrm{H}\right)$ をもつ硫酸ムコ多糖に分類されるが5110), $\mathrm{AB}$ 2.5 陽性のこれらの分泌顆粒はAB1.0では陰性とな ク,さらにメチル化処理により AB2.5 陰性となるこ とから，その糖質はシアル酸を主体とする弱酸性多糖 であった。

透過型電子顕微鏡観察では，粘液細胞の分泌顆粒は 二相性顆粒を示し, 対照群, 梼尿病ラットにおいても 著差は見られなかった。一方, 漿液細胞ではタンパク 合成の場である粗面小胞体が粘液細胞に比べよく発達 しており，対照群ラットの分泌顆粒は高電子密度で均 質な構造を呈し蛋白に富むことを示している.しかし， 糖尿病のラットの漿液細胞では，対照群と同様の内部 が均質な分泌顆粒を含む細胞と，それとは異なる粘液 細胞の分泌顆粒に類似した顆粒を含む細胞の混在が認 められた。すすなわち，その顆粒は低電子密度の明るい 基質とタンパク部分である高電子密度の不規則な形状 の凝集物からなっており，さらにその基質は精類検出 のための過ヨウ素酸-チオカルボヒドラジドープロテイ ン銀染色に陽性であったことから，分泌顆粒内の糖の 増加を示していた。このような変化は, 高齢ラットの 気管腺漿液細胞においても報告され ${ }^{11)}$, 漿液細胞の 粘液化とタンパクの減少が指摘されている.しかし, 夜陣ら゙は高齢ラットでは漿液細胞の粘液化に加え, 気管腺の導管の搪張した覀状部や，半月を伴う粘液腺 房の出現が特徵と報告しているが, 糖尿病状態の 7 力 月のラットにおいては繁液細胞の粘液化以外の所見が 認められなかったため, 今回みられた漿液細胞の変化 は加茈侴によるものではなく, 糖尿病状態に起因するこ とは明らかである。

楉尿病ラットの墏液細胞ではゴルジ装置より出た濃 縮胞がすでに不均質な形状を示しており，また同一の 細胞内ではタンパク部分である高電子密度の不規則な 形状の凝集物は類似した形状を示し，糖尿病ラットの 漿液細胞の粘液化の機序として, 細胞質における顆粒 の濃縮段階よりもむしろゴルジ装置で糖が添加される 段階で,なんらかの変化が起こっていることが考えら
れる、ゴルジ装置において糖鎖構造の特異性発現のた めに糖転移酔素がそれぞれ局在しており,ゴルジ層板 のトランス側にはシアル酸転移醉素が局在してい $る^{12113)}$. Kasuga ${ }^{11}$ は, 高齢ラットに扔ける粘液化した 漿液細胞のゴルジ装置に扔いて，トランス側の TGN が発達していることを報告している．TGN はシアル 酸添加酵素によるシアル酸添加の場であり, 糖尿病ラ ットの粘液化した漿液細胞における TGN の発達は, 分泌顆粒内のシアル酸を中心とした酸性多糖の増加に 矛盾しない所見である. Paulson ら ${ }^{14)}$ はラットの各組 織においてシアル酸転移醉素の活性が mRNAの発現 量と相関があることを示し, Wang ら ${ }^{15)}$ はデキサメ夕 ゾン投与で，シアル酸転移醭素誘導の mRNA が増加 することを報告している. インスリンとグルココルチ コイドはそれぞれ異なるレセプターを持ち，その作用 機序はなお不明な点が多いが，インスリンの久乏はシ アル酸転移酵菜の活性に影響している可能性もある。 また，粘液化した顆粒を含む細胞の出現率は糖尿病状 態が長びくにつれ増加する傾向にあり，持続した醉素 活性の変化を示すものである。

呼吸器におけるクリアランスとして，気管上部では 咳嗽, 粘液線毛クリアランスが主体をなしており, 線 毛の存在しない末梢の気管支や肺胞ではサーファクタ ントによるクリアランスが主体となっている，粘液線 毛クリアランスは，1）線毛の出力, 2) 気道液の量, 3）気道液の粘性と弾性が主要な因子になってお $\eta^{16)}$, 気道液の主体は粘膜下腺によるものである。糖氺 病ラットにおける気管上皮の線毛には形態的な変化は 見られなかったが, 漿液細胞の分泌顆粒の粘液化は気 道液の粘弾性に変化を与え，粘液線毛クリアランスに 影響を与えると考えられる。漿液細胞は防御物質のぺ ルオキシターゼ，IgAなどの蛋白を合成，分泌し局所 防御機構として直接的な役割を果たしている( ${ }^{17) 187}$. 漿 液細胞の分泌顆粒の粘液化によりそれらの防御物筫が 減少し, 粘液線毛クリアランスの変化と合わせて, 気 道の感染防御機構の低下をもたらし，糖尿病における 呼吸器疾患の発症, 憎悪の因子になることが示唆され た。

糖尿病に際しての易感染性の原因としては，一般に 白血球の食菌能抢よび殺菌作用の低下 ${ }^{1920221)}$, 高血糖 や高血糖以外の体液因子, さらに糖尿病特有の血管障 害や神経障害などが挙げられるが，詳細は不明な点が 多い. 今回の観察結果から, 上気道の易感染性に気管 腺分泌物の変化が重要な要因となっていることが明ら 
かとなり, 梼尿病患者の併発感染症の多くを占める上 気道感染症に対しては, 粘液線毛クリアランスの低下 や局所防御物質の減少に対する予防的な治療が重要と 考えられた。

\section{IV. 結 語}

糖尿病ラットの気管粘膜を観察した結果, 気管腺漿 液細胞にシアル酸を主体とする弱酸性多糖類と粘性細 胞分泌顆粒に類似の二相性構造を示す顆粒が出現し， 漿液細胞の粘液化が認められた．このような変化は， 気道に招ける感染防御機構である粘性線毛クリアラン スの低下および局所防御物質の減少を引き起こし，糖 尿病における呼吸器疾患の発生, 憎悪の因子となるこ とが推測された。

\section{文献}

1）斎藤 厚，重野芳輝，草野展周，嘉数朝一，稻留 潤 他: 糖尿病に扔ける各種感染症. 日本臨床 49：199206, 1991.

2）伊藤元彦，青木 稔：気管・気管支の機能と構造 一組 織化学的所見を中心に一 日胸 38：581-585，1979.

3) Jones $\mathrm{R}$, Reid $\mathrm{L}$ : The effect of $\mathrm{pH}$ on Alcian Blue staining of epithelial acid glycoproteins. I. Sialomucins and sulphomuchins. Histochemical J 5: 9-18, 1973 .

4) Jones R, Reid $\mathrm{L}$ : The effect of $\mathrm{pH}$ on Alcian Blue staining of epithelial acid glycoproteins. II. Human bronchial submucosal gland. Histochemical J $5:$ 19-27, 1978.

5）堀みどり，間島雄一，坂倉康夫，三吉康郎：粘液 中么コ多梼の組織学的研究. 耳鼻臨床 $77: 2435-$ 2442,1984

6）夜陣紘治，春日繁男，原田康夫：ラット気管腺の加齢 による変化．気食 $42: 330-336 ， 1991$.

7) Karnovsky $\mathrm{MJ}$ : A formaldehydeglutaraldehyde fixative of high osmolality for use in electron microscopy. J Cell Biol 27: 137a-138a, 1965.

8) Seligmann AM, Hanker JS, Wasserkrug $\mathrm{H}$ et al: Histochemical demonstration of some oxidized macromolecules with thiocarbohydorazide (T.C.H.) or thiosemicarbazide (T.S.C.) and Osmium tetrox. ide. J Histochem Cyto-chem 13: 629-639, 1965.

9) Thiery JP: Mise en évidence des polysaccharides sur coupes fines en microscopie électronique. J Microscopie 6: 987-1018, 1967.
10) Jones $R$ : The glycoproteins of secretory cells in airway epithelium. Ciba Found Symp $54: 175-$ 188, 1978.

11) Kasuga $S$ : Ultrastructural Changes in Aging Rat Tracheal Gland. Hiroshima J Med Sci $40: 63-73$, 1991.

12) Rothman JE: The Golgi apparatus. Two organelles in tandem. Science 213: 1212-1219, 1981.

13）古川 清：糖蛋白質糖鎖查の生合成と酸素. 細胞 289 : 14-21, 1991.

14) Paulson JC, Weinstein J, Schauer A : Tissuespecific expresson of sialyltransferases. $\mathrm{J}$ Biol Chem 264 : 10931-10934, 1989.

15) Wang XC, Smith TJ, Lau JTY: Transcriptional regulation of the liver $\beta$-galactoside $\alpha 2,6$-sialyltrasferase by glucocorticoides. J Biol Chem. 265 : 17849-17853, 1990.

16) King $M$ : Rheological requirements for optimal clearance of secretions: ciliary transport versus cough. Enrop J Respir Dis 61: 39-45, 1980.

17）伊藤元彦，長瀬千秋，光岡明夫，永田明義，原田孝之 他：気管支腺の機能と構造に関する研究. 日胸 15 ： 186-190, 1997

18）伊藤元彦，玉田二郎，青木 稔：気道分泌液の機能と 構造. 日胸 $19: 926-931 ， 1981$.

19) Mowat AG, Baum J: Chemotaxis of polymorphonuclear leucocytes from patients with diabetes mellitus. N Engl J Med 284:621-627, 1971.

20) Rayfield EJ, Ault MJ, Keusch GT et al : Infection and diabetes, the case for glucose control. Am J Med $72:$ 439-450, 1982.

21) Nolan CN, Harry NB, Bagdade JD: Further characterization of the impaired bactericidal function of granulocytes in patients with poorly controlled diabetes. Diabetes 27: 889-894, 1978.

稿を終えるにあたり、ご指導ここ校閱いただきました 原田康夫教授に深謝いたします。また，研究にご協力いただ いた工田昌也講師，春日繁男研究員をはじめ教室員の皆様 に厚く招礼申し上げます。

(1993年 4 月21日受稿 1993 年 6 月 3 日受理 急載) 別刷請求先 テ729-03 広島県三原市系崎町3765 三菱三原病院耳鼻咽喉科 津田哲也 


\section{津 田論文 付図}

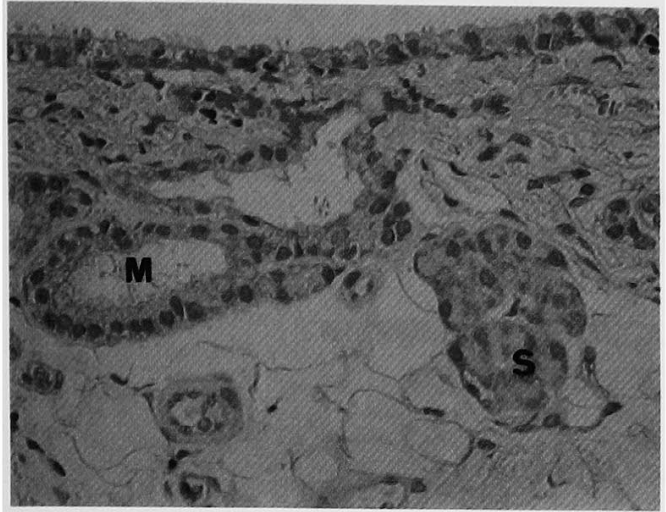

図 2 対照群ラット気管腺 粘液細胞からなる粘液管（M）と，漿 液細胞からなる漿液腺房（S）により 構成される. H\&E染色.

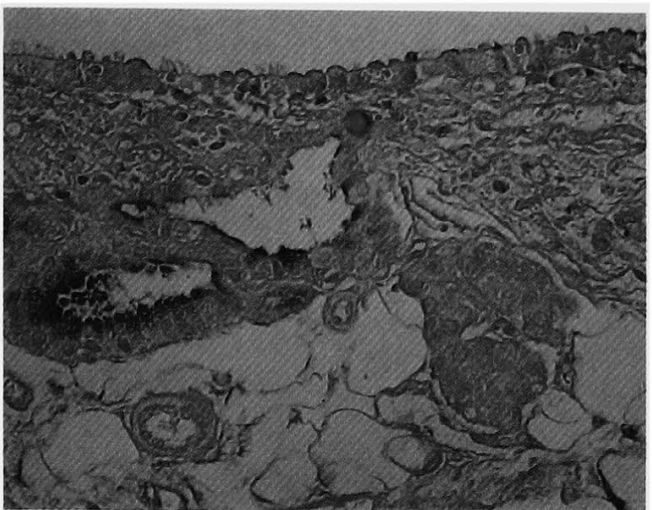

図 3 対照群ラット気管腺

粘液細胞は AB, PAS 両者に陽性で あったが, 漿液細胞はPAS反応のみ に陽性で，中性糖タンパクが主体をな している. AB 2.5 PAS 反応.

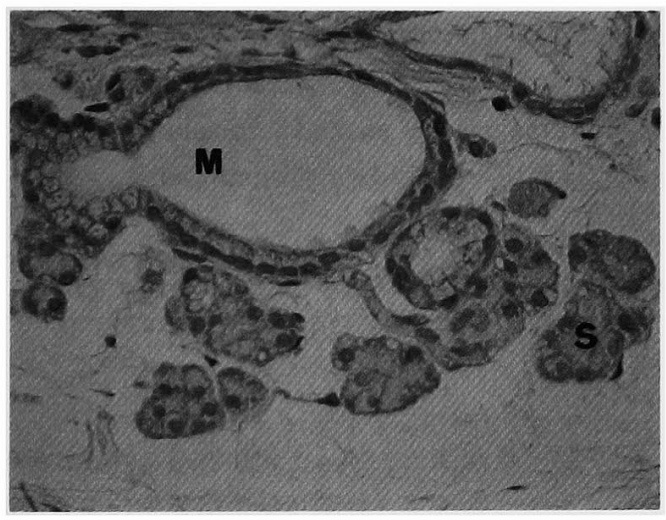

图 4 糖尿病状態 3 力月ラット気管腺 気管腺の分布状態は対照群のものと著 差はなく，粘液細胞からなる粘液管 （M）と, 漿液細胞からなる漿液腺房 （S）により構成される．H＆E染色.

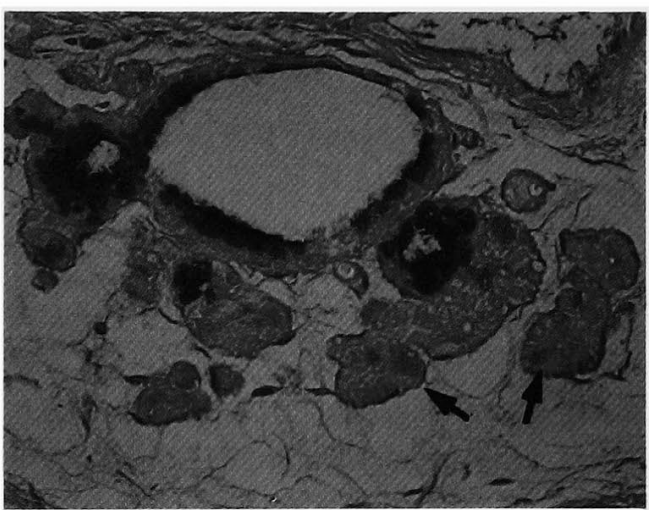

図 5 糖尿病状態 3 力月ラット気管腺 一部の漿液細胞の分泌顆粒が青紫色に 染色され (矢印), 中性糖タンパクお よび酸性糖タンパクの両者を含んでい る. AB 2.5 PAS 反応. 


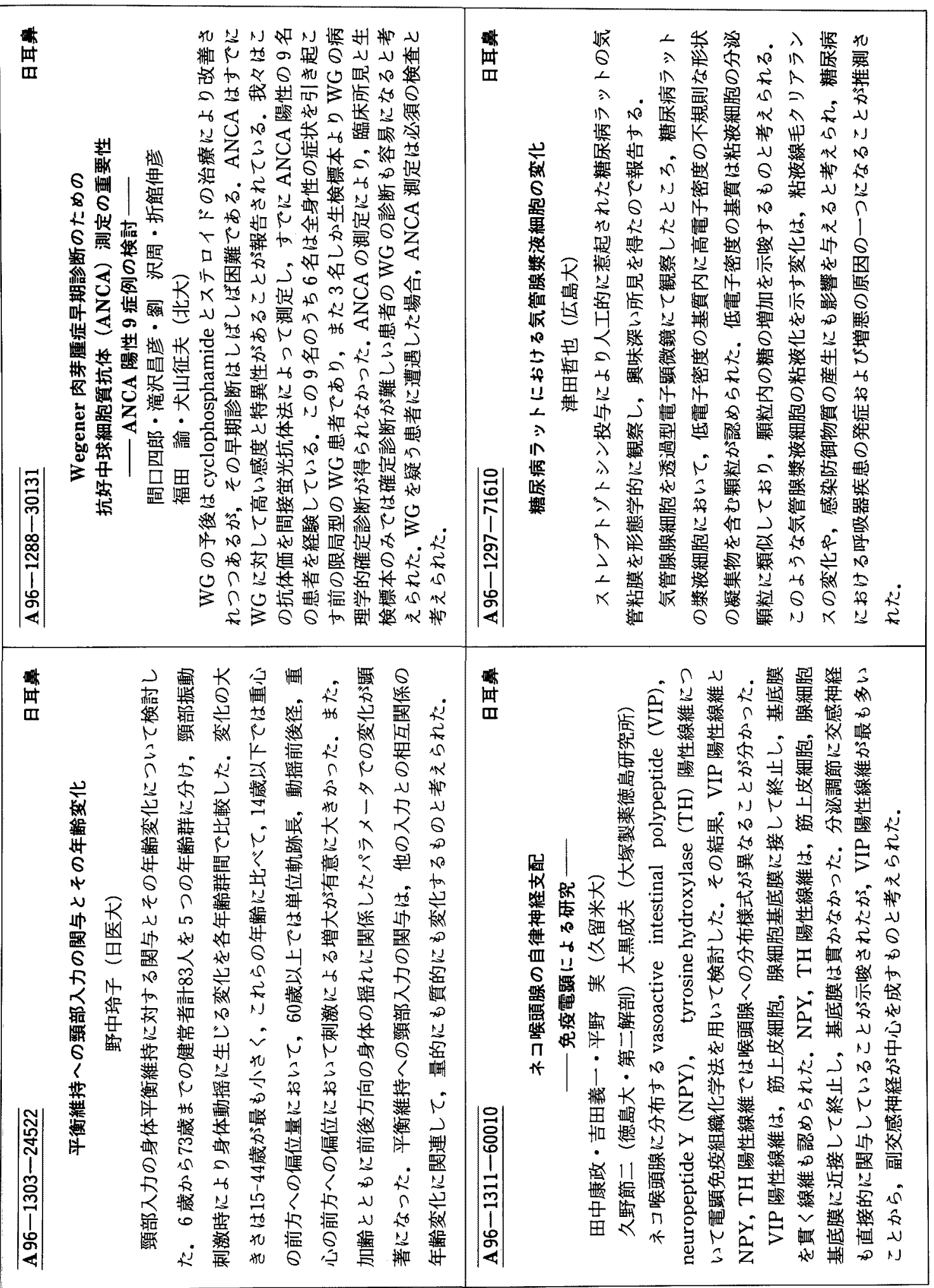

